\title{
Brand Authenticity as a Mediator of Relationship Between Self-Congruity and Consumer Loyalty
}

\author{
Susilo Hidayat ${ }^{1}$, Farida Agus Setiawati ${ }^{2}$ \\ ${ }^{1}$ Department of Psychology, Faculty of Education, Universitas Negeri Yogyakarta \\ Jl. Colombo No. 1 Sleman Yogyakarta, 55281. \\ ${ }^{1}$ hidayatsusilo123@gmail.com; ${ }^{2}$ farida_as@uny.ac.id
}

\begin{abstract}
This study investigates the effect of brand authenticity as a mediator of self-congruity relationships on coffee shops consumer loyalty. Data obtained by cross-sectional method with convenience/accidental sampling through an online survey platform. Four hundred thirty responses (44.4\% male) were collected from consumers of various brands of coffee shops located in DIY. The mediation effect hypothesis was tested using a bootstrapping approach and additional analysis of the causal step approach using the Sobel test. Self-congruity and brand authenticity have a positive effect on brand loyalty. There is a partial mediating effect produced by brand authenticity on the relationship between self-congruity and brand loyalty. Consumers' consideration to be loyal to the brand is not only based on the suitability of their self-concept with the brand image/brand users image (self-congruity), but also the brand's authenticity.
\end{abstract}

Keywords: Brand authenticity, brand loyalty, self-congruity, and coffee shop

\section{Introduction}

Indonesia is one of the four major coffee bean exporters globally, with a total production of 760.96 thousand tons in 2019 (Pusat Data dan Sistem Informasi Pertanian, 2020:41). The value of Indonesia's coffee exports is predicted to decline by an average of $0.41 \%$ every year, in line with the increase in domestic coffee consumption by $3.07 \%$ (Pusat Data dan Sistem Informasi Pertanian, 2020:57). This prediction refers to a $13.9 \%$ increase in domestic consumption of coffee commodities, from 250 thousand tons in 2018 to 294 thousand tons in 2020. This shows the growth of the domestic coffee processing industry, which is directly proportional to the increasing trend of consumption of coffee products in the community.

Mix Marketing \& Communication Magazine and Toffin (2019) confirmed the increasing trend of coffee consumption in Indonesia in a research report published in 2020. The trend of coffee consumption is growing in terms of increasing the number of modern coffee shops/coffee shops. The number of coffee shops in Indonesia initially amounted to 1083 in 2016 (stores of various brands), then increased three times in 2019 to 2937 shops.

One of the areas experiencing a growing trend of coffee consumption is the province of Yogyakarta. At least 250 coffee shops from various brands run business activities in this province (the search entry results on the Traveloka Eats platform). In the official prospectus document of Bento Kopi (a coffee shop in DIY) on the Santara.co.id website, it was recorded that in 2018 there were around 1100 coffee shops throughout DIY (PT Muda Bangun Semesta, 2020). Quoting Agus Prasetyo, on 
the bernas.id said that there were only 350 coffee shops in 2014, an increase of 600 in 2015, and finally 1000 in 2018 (Bernas.id, 2018). This is similar to Ranu Prasetyo, Marketing Communications Manager of Ralali.com and an expert on digital business in Indonesia. He stated that in 2017, the number of coffee shops in Yogyakarta and its surroundings reached 1200 . This figure is much higher than the nearest big cities such as Semarang with 700 coffee shops and Solo with around 400 coffee shops (Selular.id, 2018).

The high growth of coffee shops raises classic problems in business competition. From the perspective of businesspeople, consumer loyalty to a brand is critical to ensure the sustainability of coffee shop business activities. Maintaining consumer loyalty to the brand is very important to strengthen the brand (Kotler \& Keller, 2016). Brand loyalty occurs when consumers are satisfied with the quality of the product/service of a brand compared to other brands. Consumers consciously evaluate their behavior and repeat purchases at the same brand (Jacoby \& Kyner, 1973).

Brand loyalty measures the extent to which consumers are committed to buying brands regularly (Schiffman \& Wisenblit, 2019). Consumers' deeply held commitment to re-buy or re-subscribe to a preferred product or service consistently. However, situational influences and marketing efforts can cause behavioral switching (Oliver, 2010).

Quality and authentic products can increase consumer satisfaction and brand loyalty (Alhaddad, 2015; Andervazh et al., 2016; Hong-Youl Ha, 2012; Kassim et al., 2014). In the postmodern era, problems arise in terms of authenticity. These problems cause consumers to feel like they are in the middle of a market filled with various brands, especially coffee shop brands. Coffee shop brands compete and try to "grab the hearts" of potential consumers to buy the product. This creates a condition of hyperreality (Baudrillard, 1995:3). The hyperreality condition makes it difficult for consumers to identify which brands are "authentic" and which brands are "fake" (Arnould \& Price, 2000; Firat \& Venkatesh, 1995). Fake is not interpreted as "imitation" or "imitation".

Consumer demand for authenticity is natural and inevitable. Authenticity is essential for consumers because it reduces the complexity of globalization, minimizes risk, advocates for loss of trust in brands, homogenization, and deals with brands with similar and ubiquitous products (Christine \& Prinsloo, 2015). In addition, the critical attitude, cynicism, skepticism, and consumer distrust of the brand raises consumer resistance. Resistant consumers tend to be sensitive to authenticity and understand which brands are authentic (Christine \& Prinsloo, 2015).

The coffee business competition has become a competition in the Red Ocean with the proliferation of new coffee shops. In the red ocean business competition, coffee brands are likened to a shark that pounces on each other (Kim \& Mauborgne, 2015a). Business owners must be able to create new markets by offering innovative new values (Kim \& Mauborgne, 2015b). Value innovation means that each store must show something truly authentic and unique to consumers to foster brand loyalty.

Morhart, Malär, Guèvremont, Girardin, \& Grohmann (2015) state that an authentic brand is a brand that is consistent and able to last over time (continuous), loyal to consumers (credible), has care and responsibility (integrity) and can support consumers, to be honest with themselves/express themselves (symbolism). Authenticity is a precious asset for brands (Kotler et al., 2017), especially for brands that want to be "survive" and "sustainable".

Apart from authenticity, consumers generally tend to be more attached to products, services, and brands that express essential aspects of themselves, such as self- 
identity, values, and goals (AguirreRodriguez et al., 2012). Active consumers choose products from brands according to their tastes or preferences. Consumers are sometimes faced with several choices of brands that have equally strong product quality and authenticity. Although product quality and authenticity are equivalent, consumers will be reluctant to buy and subscribe to a brand if they are not "tasteful" or "not suitable". Therefore, in addition to brand authenticity, consumer loyalty to the brand can also be determined from how "fit" a brand is with one's selfconcept (self congruity) (Kang, Tang, \& Lee, 2015; Shamah, Mason, \& Moretti, 2018).

Self-congruity is a process as well as a psychological outcome that occurs when consumers compare their perceptions of brand image (brand personality or brand user image) with their self-concept (actual self, ideal self, social self) (Sirgy, 2018).

\section{Methods}

This study is quantitative, ex-postfacto research. This study tries to ascertain or establish relationships between at least two aspects of the problem/phenomenon in research, and sometimes, to replicate these relationships to strengthen their reliability and validity (Hackett, 2018).

\section{Research Subjects}

The minimum number of samples for this research is $385-400$ subjects. We obtained 430 responses (44.4\% male) from consumers of various brands of coffee shops located in Yogyakarta.

\section{Research Instruments}

This study uses primary data obtained from the process of measuring research variables on consumers using a psychological scale that is distributed online. The scale used is Perceived Brand Authenticity ( 7 points Likert) adapted from Morhart et al. (2015). The Brand Loyalty
Scale (7 Likert Points) was adapted from Kang et al. (2015), and the self-congruity scale (5 points Likert) was adapted from Sirgy \& Su (2000) and Kang et al. (2015). Data was obtained through the accidental sampling method.

\section{Data Analysis}

Hypothesis testing was carried out using a bootstrapping approach (Hayes, 2018) and additional analysis of the causal step with the Sobel test as suggested by Baron \& Kenny (1986). This study applies a simple mediation model because it only involves one mediator variable. In addition, multiple regression analysis was conducted to determine the effect of each independent variable outside the framework of mediation analysis.

\section{Findings}

Descriptive analysis of the scores of each research variable is shown in the diagram below:

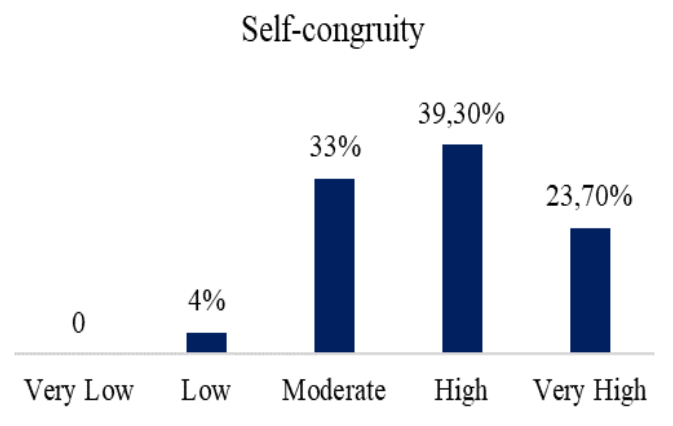

Figure 1. Self-congruity Frequency

Distribution

Self-congruity scores in the low category are $4 \%$ of 430 total subjects, moderate category $33 \%$ of 430 total subjects, high category $39.3 \%$ of 430 total subjects, and the very high category $23.7 \%$ of 430 total subjects. 


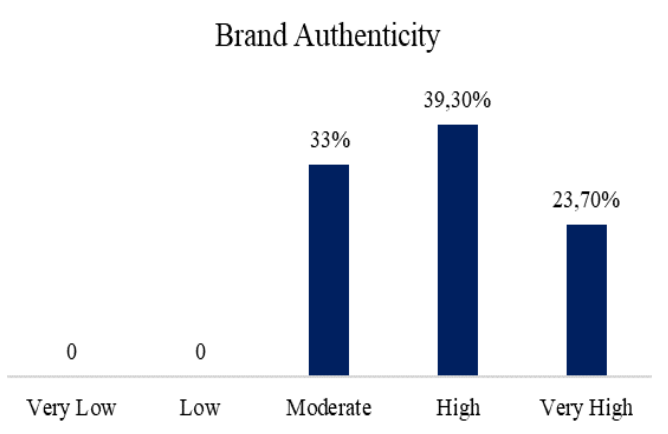

Figure 2. Brand Authenticity Frequency

Distribution

Then the Perceived Brand Authenticity scores in the moderate category are $33 \%$ of 430 total subjects, high category $39.3 \%$ of 430 total subjects, and the very high at $23.7 \%$ of 430 total subjects.

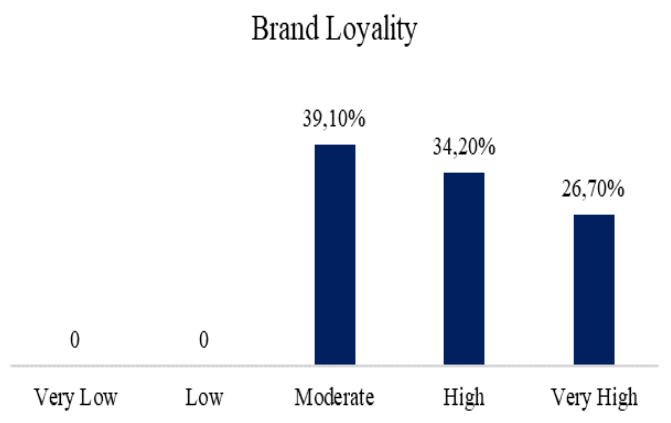

Figure 3. Brand Loyalty Frequency

Distribution Diagram

On brand loyalty, the scores in the moderate category are $39.1 \%$ of 168 subjects. Then in the high score category, the percentage was $34.2 \%$ from 147 subjects, and the very high category was $26.7 \%$ from 115 subjects.

The results of the multiple regression analysis tests showed that selfcongruity has a positive effect on brand loyalty $(\beta=0.1990, t(429)=4.999, p<0.0)$. Meanwhile, brand authenticity also has a positive effect on brand loyalty $(\beta=0.6003$, $\mathrm{t}(429)=15,077, \mathrm{p}<0.05)$.

From the results of the regression test, a multiple regression equation can be formulated:

$$
\mathrm{Y}=3,985+0,199 \mathrm{X}_{1}+0,600 \mathrm{X}_{2}
$$

The results of further calculations show that the effective contribution (SE) of the self-congruity and brand authenticity variables to brand loyalty is $53.3 \%$. With an effective contribution value of $10.6 \%$ for self-congruity and $42.7 \%$ for brand authenticity. The value of $53.3 \%$ can be interpreted that the variance of brand loyalty scores can be effectively explained by the two independent variables of $53.3 \%$. Meanwhile, the remaining $46.7 \%$ is explained by other variables not involved in this study.

Sobel test produces a $t$ value of 3.332. This value is greater than the t-table value of this study, which is 1.648 (onetailed, $\mathrm{p}=0.05$ ). It can be concluded that the brand authenticity variable can act as a mediator of the relationship between selfcongruity and brand loyalty because it has a t-count value of $3.3322>$ t-table 1.648.

Hypothesis testing using a bootstrapping approach was carried out to find out how the mediating effect of the brand authenticity variable on the selfcongruity relationship on brand loyalty was carried out. The test was carried out using the PROCESS 3.5 plug-in on SPSS. The results of the mediation analysis are shown in table 1 . The regression coefficients listed in table 1 can be manifested in a model diagram in Figure 4. 


\section{Brand Authenticity as a Mediator of Self-Congruity and Consumer Loyalty Hidayat \& Setiawati}

Table 1. Mediation Test Results

\begin{tabular}{|c|c|c|c|c|c|c|c|c|}
\hline \multirow{3}{*}{ Independent } & \multicolumn{8}{|c|}{ Dependent } \\
\hline & \multicolumn{4}{|c|}{ M (Authenticity) } & \multicolumn{4}{|c|}{ Y (Loyalty) } \\
\hline & & Coeff. & SE & $p$ & & Coeff. & SE & $p$ \\
\hline $\mathrm{X}$ (Self-congruity) & $a$ & .5568 & .1661 & $<.001$ & $c^{\prime}$ & ,1990 & ,1171 & $<.001$ \\
\hline M (Authenticity) & & - & - & - & $b$ & 6003 & ,0283 & $<.001$ \\
\hline \multirow[t]{3}{*}{ constant } & $i_{M}$ & 47,28 & 2,047 & $<.001$ & $i_{Y}$ & 3,985 & 1,903 & $<.001$ \\
\hline & \multicolumn{5}{|c|}{$\mathrm{R}^{2}=, 3100$} & \multicolumn{3}{|c|}{$\mathrm{R}^{2}=, 5330$} \\
\hline & \multicolumn{5}{|c|}{$\mathrm{F}=192,2953, p<.001$} & \multicolumn{3}{|c|}{$\mathrm{F}=243,6620, p<.001$} \\
\hline
\end{tabular}

Figure 4. Path plot of mediation test

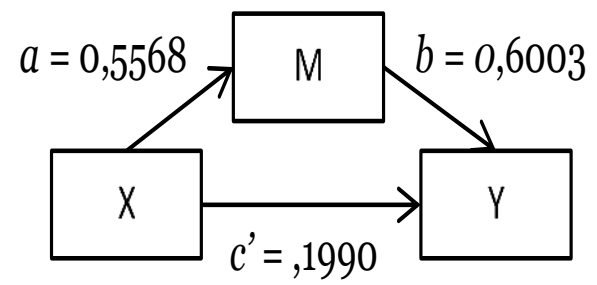

From the results of the analysis, it is known that the percentage value of the indirect effect $(62.7 \%,=0.3342, \mathrm{p}<0.05)$ is greater than the direct effect $(37.3 \%$, = $0.1990, \mathrm{p}<0.05)$.

\section{Discussion}

Consumers sometimes consume something according to their self-concept (Malhotra, 1988). Self-concept is an individual's awareness of experience, existence, perspective, and attitude towards himself. In addition, consumers also tend to be more attached to products, services, and brands that express essential aspects of themselves, such as self-
Table 1. Mediation Percentage

\begin{tabular}{llll}
\hline Effect & Label & Coeff. & $\%$ \\
\hline Indirect & $a \times b$ & .3342 & 62.7 \\
Direct & $c^{\prime}$ & .1990 & 37.3 \\
Total & $c '+a \times b$ & .5333 & 100.0 \\
\hline
\end{tabular}

identity, values, and life goals (goals) (Aguirre-Rodriguez et al., 2012). Brand image and brand user image have a close relationship with self-concept. When the consumer's self-concept is in accordance with the impression/image of the brand or brand users (shop visitors), it can be said that self-congruity occurs.

This study states that selfcongruity has a significant effect on brand loyalty. It can be said that the more appropriate the consumer's self-concept with the brand image or brand user image, the higher the consumer's tendency to foster loyalty.

In addition to product conformity with self-concept (self-congruity), 
consumers want quality products that meet their needs and are authentic. Consumer demand for authenticity is natural and inevitable. Authenticity is essential for consumers because it reduces the complexity of globalization, minimizes risk, advocates for loss of trust in brands, homogenization, and deals with brands with similar and ubiquitous products (Christine \& Prinsloo, 2015). In addition, the critical attitude, cynicism, skepticism, and consumer distrust of the brand raises consumer resistance. Resistant consumers tend to be sensitive to authenticity and understand which brands are authentic (Christine \& Prinsloo, 2015).

The analysis results show that the authenticity perceived by consumers of the brand significantly affects brand loyalty. The higher the consumer's perception of the authenticity of a brand, the more loyalty will grow. This can happen because the authentic brand consumers get guaranteed products and excellent service. Brands that can survive for a long time have high credibility and integrity and support consumers to be themselves make consumers believe so that the possibility of consumers being loyal is high.

The results of the mediation test can be interpreted that consumers will experience a more substantial selfcongruity effect if the brand is perceived as authentic. Authentic brands guarantee consumers good product quality, thus enabling the growth of brand loyalty. Authentic brands become a platform for consumers to develop brand trust, which can later be developed into loyalty. Consumers choose authentic brands that can be used to express important aspects of themselves, such as self-identity, values, and goals (Aguirre-Rodriguez et al., 2012). In the end, consumers will be loyal to brands that are reliable and entirely responsible for customer satisfaction and in accordance with the self-concept of consumers.

\section{Conclusion}

Based on the research that has been carried out, it can be concluded that self-congruity and brand authenticity positively affect brand loyalty. The results of the mediation test explain that brands that are seen as authentic by consumers will tend to produce a more substantial self-congruity effect. This can be interpreted that authenticity has a crucial role in the consumer's decision to be loyal or not, associated with whether or not the consumer's self-concept is appropriate with the brand personality and/or brand user image.

\section{Suggestion}

Authenticity and self-congruity can be effective predictors to determine consumer loyalty to the brand. For brands, authenticity must be developed or highlighted to increase consumer loyalty. In addition, the effect of self-congruity must also be developed by setting clear targets and market segmentation (niche marketing).

\section{References}

Aguirre-Rodriguez, A., Bosnjak, M., \& Sirgy, M. J. (2012). Moderators of the self-congruity effect on consumer decision-making: A metaanalysis. Journal of Business Research, 65(8), 1179-1188. https://doi.org/10.1016/j.jbusres.2 011.07.031

Alhaddad, A. (2015). Perceived quality, brand image and brand trust as determinants of brand loyalty. Journal of Research in Business and Management, 3(4), 01-08. https://www.researchgate.net/prof ile/Abdullah_Alhaddad2/post/Can _you_suggest_me_some_good_liter ature_reviews_on_brand_loyalty_a nd_other_papers_that_are_focused 
_on_millennials_attitude_to_be_loy al_to_brands/attachment/5a1d118 b4cde267c3e6f336f/AS\%3A56557 281

Andervazh, L., Shohani, M., Tamimi, H., Diyaleh, P., \& Alnasere, S. (2016). The Effects of brand perceived quality and awareness on brand loyalty (Case Study: Carbonated drinks). International Journal of Advanced Biotechnology and Research (IJBR), 7, 202-209. http://www.bipublication.com

Arnould, E., \& Price, L. (2000). Authenticating acts and authoritative performances. In S. Ratneshwar, D. G. Mick, \& C. Huffman (Ed.), The Why of Consumption: Contemporary Perspectives on Consumers' Motives, Goals, and Desires (hal. 138). Routledge.

Baron, R. M., \& Kenny, D. A. (1986). The moderator-mediator variable distinction in social psychological research: Conceptual, strategic, and statistical considerations. Journal of Personality and Social Psychology, 51(6), 1173-1182.

https://doi.org/10.1037/00223514.51.6.1173

Baudrillard, J. (1995). Simulacra and Simulation. University of Michigan Press.

Bernas.id. (2018). Bisnis Warung Kopi Di Yogyakarta Cukup Menjanjikan. In Bernas.id. Bernas.id. https://www.bernas.id/63451bisnis-warung-kopi-di-yogyakartacukup-menjanjikan

Christine, M., \& Prinsloo, M. (2015). Authenticity in marketing: a response to consumer resistance? Journal of Marketing and Consumer Behaviour in Emerging Markets, 2015(2), 15-32. https://doi.org/10.7172/24496634.jmcbem.2015.2.2
Firat, A. F., \& Venkatesh, A. (1995). Liberatory postmodernism and the reenchantment of consumption. Journal of Consumer Research, 22(3), 239.

https://doi.org/10.1086/209448

Hackett, P. M. W. (2018). Quantitative Research Methods in Consumer Psychology. Routledge. https://doi.org/10.4324/97813156 41577

Hayes, A. F. (2018). Introduction to Mediation, Moderation, and Conditional Process Analysis: A Regression-Based Approach (2 ed.). The Guildford Press.

Hong-Youl Ha. (2012). Effects of perceived quality and satisfaction on brand loyalty in China: The moderating effect of customer orientation. African Journal of Business Management, 6(22), 6745-6753. https://doi.org/10.5897/AJBM12. 236

Jacoby, J., \& Kyner, D. B. (1973). Brand loyalty vs. repeat purchasing behavior. Journal of Marketing Research, 10(1), 1. https://doi.org/10.2307/3149402

Kang, J., Tang, L., \& Lee, J. Y. (2015). Selfcongruity and functional congruity in brand loyalty. Journal of Hospitality and Tourism Research, 39(1), 105-131. https://doi.org/10.1177/10963480 12471377

Kassim, A. W. M., Igau, O. a., Harun, A., \& Tahajuddin, S. (2014). Mediating effect of customer satisfaction on perceived product quality, perceived value, and their relation to brand loyalty. International Journal of Research in Management \& Business Studies (IJRMBS), 1(2). 
Kim, W. C., \& Mauborgne, R. (2015a). Red Ocean Traps. The mental models that undermine marketcreating strategies. Harvard Business Review, 68-74. http://www.aurovikas.co.in/os201 9/upload1/resources/RedOceanTr aps.pdf

Kim, W. C., \& Mauborgne, R. A. (2015b). Blue Ocean Strategy (Expanded Edition): How to Create Uncontested Market Space and Make the Competition Irrelevant (Expanded). Harvard Business Review Press.

Kotler, P., Kartajaya, H., \& Setiawan, I. (2017). Marketing 4.0: Moving from Traditional to Digital. John Wiley \& Sons.

Kotler, P., \& Keller, K. L. (2016). Marketing Management (15 ed.). Pearson.

Malhotra, N. K. (1988). Self-concept and product choice: An integrated perspective. Journal of Economic Psychology, 9(1), 1-28. https://doi.org/10.1016/01674870(88)90029-3

Morhart, F., Malär, L., Guèvremont, A., Girardin, F., \& Grohmann, B. (2015). Brand authenticity: An integrative framework and measurement scale. Journal of Consumer Psychology, 25(2), 200-218. https://doi.org/10.1016/j.jcps.201 4.11 .006

Oliver, R. L. (2010). Satisfaction: A behavioral perspective on consumer (2 ed.). Routledge.

PT Muda Bangun Semesta. (2020). Prospektus BENTO KOPI. https://www.santara.co.id/uploads /token/BNTO_prospektus.pdf
Pusat Data dan Sistem Informasi Pertanian Sekretariat Jenderal Kemeterian Pertanian Republik Indonesia. (2020). Buku Outlook Komoditas Perkebunan Kopi Tabun 2020.

http:/ / epublikasi.setjen.pertanian.g o.id/

Schiffman, L. G., \& Wisenblit, J. (2019). Consumer Behavior (12 ed.). Pearson. https://doi.org/10.1088/17518113/44/8/085201

Selular.id. (2018). Ralali Tangkap Peluang Bisnis Kedai Kopi di Yogyakarta. In Selular.ID. https://selular.id/2018/03/ralalitangkap-peluang-bisnis-kedai-kopidi-yogyakarta/

Shamah, R. A. M., Mason, M. C., Moretti, A., \& Raggiotto, F. (2018). Investigating the antecedents of African fast-food customers' loyalty: A self-congruity perspective. Journal of Business Research, 86(October 2016), 446-456. https://doi.org/10.1016/j.jbusres.2 017.05.020

Sirgy, M. J. (2018). Self-congruity theory in consumer behavior: A little history. Journal of Global Scholars of Marketing Science, 28(2), 197-207. https://doi.org/10.1080/21639159. 2018.1436981

Sirgy, M. J., \& Su, C. (2000). Destination image, self-congruity, and travel behavior: Toward an integrative model. Journal of Travel Research, 38(4), 340-352. https://doi.org/10.1177/00472875 0003800402

Toffin, \& Majalah MIX. (2019). 2020 Brewing in Indonesia: Insights for Successful Coffee Shop Business. 